\title{
Dynamics of the land use, land use change, and forestry sink in the European Union: the impacts of energy and climate targets for 2030
}

\author{
Stefan Frank ${ }^{1}$ - Hannes Böttcher ${ }^{2}$ - Mykola Gusti ${ }^{1,3}$. \\ Petr Havlík $^{1}$ - Ger Klaassen ${ }^{4}$ - Georg Kindermann ${ }^{1}$ • \\ Michael Obersteiner ${ }^{1}$
}

Received: 4 December 2014 / Accepted: 17 June 2016/Published online: 8 July 2016

(C) The Author(s) 2016. This article is published with open access at Springerlink.com

\begin{abstract}
A 2030 climate and energy policy framework was endorsed by the European Council in 2014. The main elements are a binding $40 \%$ greenhouse gas (GHG) reduction target compared to 1990, a renewable energy share of $27 \%$, and an energy savings target of at least $27 \%$ by 2030 . In this paper, we assess the impact of these targets on the European land use, land use change, and forestry (LULUCF) sector using a Europe focused global land use model linked with a detailed forest management model. We show that implementing a $40 \%$ GHG emission reduction target by 2030 may only have a small negative impact on the domestic LULUCF sink if the additional biomass demand for energy is mostly met through ligno-cellulosic energy crops rather than forest removals. However, if the increased biomass demand were met through higher rates of forest harvest removals, a more negative impact on the LULUCF sink could be expected.
\end{abstract}

\section{Introduction}

The land use, land use change, and forestry (LULUCF) sector is a large carbon sink in the European Union (EU), absorbing substantially more carbon than it emits. According to United

Electronic supplementary material The online version of this article (doi:10.1007/s10584-016-1729-7) contains supplementary material, which is available to authorized users.

Stefan Frank

frank@iiasa.ac.at

1 International Institute for Applied Systems Analysis, Vienna, Austria

2 Öko-Institut, Berlin, Germany

3 Lviv Polytechnic National University, Lviv, Ukraine

4 European Commission, Brussels, Belgium 
Nations Framework Convention on Climate Change (UNFCCC) inventory data, the land use carbon sink in the EU was estimated to amount to $329 \mathrm{MtCO}_{2}$ in 2012 . The forest sector in particular has sequestered significant amounts of carbon over the past 50 years (Bellassen et al. 2011). Although forest harvest has increased steadily, improved forest management and establishment of new forests have outweighed this, resulting in a continued net sink (Ciais et al. 2008). Grasslands in the EU countries also form a carbon sink, especially those that have been recently converted from cropland (Soussana et al. 2004). Emissions from deforestation and cropland soils do reduce the total carbon sequestered by forests and grassland; however, deforestation rates in EU countries are relatively stable at a low level (UNFCCC).

In 2009, the EU committed to the so called climate and energy package to reduce greenhouse gas (GHG) emissions in 2020 by $20 \%$ compared to 1990 and increase the share of renewable energy in final energy consumption to $20 \%$ (Delbeke and Vis 2015; EC 2009). In addition, the EU also agreed to reduce gross inland consumption of energy by $20 \%$ in 2020 (EC 2014). Depending on implementation of the Renewable Energy Directive, energy efficiency progress, and the impact of policies to reduce GHG emissions, biomass from forests and agriculture is expected to contribute substantially to reaching the renewable energy and GHG targets.

In the long run, the EU aims at reducing GHG emissions by 80-95\% in 2050 compared to 1990 (EC 2011). As a step towards meeting the 2050 targets and to keep on track after 2020, a 2030 climate and energy policy framework (EC 2014) was endorsed by the European Council in 2014. ${ }^{1}$ The main element of the framework is a binding $40 \%$ GHG reduction target compared to 1990 by 2030, an EU-wide renewable energy share of at least $27 \%$, and an EU-wide energy savings target of at least $27 \%$ (and up to $30 \%$ ) by 2030 (expressed as a percentage reduction in gross inland energy consumption in 2030 compared to the "businessas-usual" projection made in 2007 for the year 2030 (EC 2014)).

These climate and energy policies can potentially trigger direct and indirect effects both within and outside Europe via international trade (Laborde 2011). Changes in forest management towards shorter rotations, higher extraction rates of primary forestry residues etc. may occur, and in agriculture there may be shifts towards more dedicated energy crops, higher straw extraction rates, and conversion of grassland to energy crops (IPCC 2014). Over the past decade, there have also been the first signs of a saturation of the forest sink. The stem volume increment has declined related to forest ageing, for instance, and net afforestation area is decreasing (Fuchs et al. 2015) as a result of more intensive land use and increase of natural disturbances such as fire, storm, or insects (Nabuurs et al. 2013). In addition, increasing demand for forest products (Mantau et al. 2010) may result in a further reduction of the forest sink. Böttcher et al. (2012) estimate that the forest sink could decline by around 25-40\% (65$125 \mathrm{MtCO}_{2}$ ) until 2030 compared to 2010, partly due to increasing biomass demand for energy. Land use changes and changes in management and extraction rates both affect biomass and soil carbon pools of ecosystems, which can reduce the amount of carbon sequestered by the land or even result in net $\mathrm{CO}_{2}$ emissions. There is therefore a potential conflict between policies targeting the reduction of emissions and the increase of sinks through land use activities and the increased use of biomass for energy production (Obersteiner et al. 2010).

In this article, we enhance the Global Biosphere Management Model (GLOBIOM) linked with a forest management model $(\mathrm{G} 4 \mathrm{M})$ to provide detailed representation of the European LULUCF sector and cropland soil carbon dynamics. We use the newly developed tool to

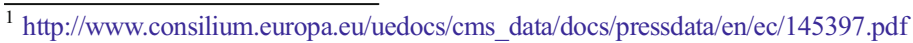


assess impacts of the proposed $40 \%$ GHG reduction target (excluding LULUCF) (EC 2014) in combination with different targets for energy efficiency and/or renewable energy shares on the EU LULUCF sector. We quantify a series of alternative 2030 climate and energy scenarios (EC 2014) to assess the impact on the LULUCF net sink. We explicitly represent emissions from the forestry and agricultural sector including emissions from land remaining cropland, grassland, and forests as well as emissions from land converted to and from those categories.

\section{Methods}

In our analysis, we estimate current and future $\mathrm{CO}_{2}$ emissions from the EU LULUCF sector for an updated European Reference scenario 2013 using GLOBIOM-EU linked with G4M. The remainder of this section briefly describes the scenarios, the models and their linkage, and explains how LULUCF emissions are estimated.

\subsection{Model descriptions}

\subsubsection{GLOBIOM-EU}

GLOBIOM-EU is a variant of the GLOBIOM model (Havlík et al. 2014), a global recursive dynamic partial equilibrium bottom-up model integrating the agricultural, bioenergy, and forestry sectors where the EU28 countries are represented in great detail. In the objective function, the global agricultural and forest market equilibrium is computed by choosing land use and processing activities to maximize the sum of producer and consumer surplus subject to resource, technological, demand, and policy constraints. Demand and international trade are represented at the level of 53 aggregated world regions (28 EU member countries, 25 regions outside EU). The supply side of the model is based on a detailed disaggregation of land into Simulation Units (SimUs) which are aggregates of 5 arcmin pixels based on biophysical soil characteristics, i.e., altitude, slope, soil class, and spatial location (Skalský et al. 2008). Information on land cover in Europe is based on CORINE 2000 and Global Land Cover 2000 is used outside Europe.

Crop, grass, forest, and short rotation tree productivity is estimated together with related environmental parameters at the level of SimUs, either by means of process based bio-physical models or by means of downscaling from national statistics. On the crop production side outside Europe, the model represents 18 major crops and 4 different management systems (irrigated, high input - rainfed, low input - rainfed, and subsistence) simulated with the biophysical process based model EPIC (Williams 1995). For the European crop sector, EPIC simulations with detailed representation of management systems (3 tillage systems - conventional, reduced and minimum tillage and 2 fertilizer and irrigation systems), crop rotations, additional crops and soil carbon dynamics are incorporated. The model currently covers the 18 most important crops in the EU (Frank et al. 2015).

Parameters for primary forest production such as mean annual increment, maximum share of saw logs in harvested biomass, and harvesting costs are provided by the G4M model (see below). Six land use types are represented in the model (cropland, grassland, short rotation tree plantation, managed forests, natural forests, and other natural land) which can be converted into each other depending on the demand and profitability of the different land based activities. Within Europe, we assume no deforestation for agricultural area expansion due to restrictive land use legislation (Bauer et al. 2004). For a more detailed description of GLOBIOM-EU see Frank et al. (2015). 


\subsubsection{G4M}

G4M (Gusti 2010; Kindermann et al. 2008) is a spatially explicit (currently on a $0.5^{\circ} \times 0.5^{\circ}$ resolution) model simulating land use change and forest management decisions and estimating respective $\mathrm{CO}_{2}$ emissions. The model incorporates empirical forest growth functions for major tree species. The land use change decisions (afforestation or deforestation) are made by comparing the net present value of managed forest with income by alternative land use in the same place. The forest management decisions are driven first by wood demand, then forest productivity, net present value of forestry in comparison to income through alternative land uses, proximity to populated places, etc. (Gusti 2010). Since the model does not represent either forest markets or other economic sectors, it has to rely on other sources - models or databases - for information such as wood prices, land rents, urban sprawl, natural disturbances, and land available for afforestation. As output, G4M produces estimates of: forest area changes, carbon sequestration and emissions from forests, impacts of carbon incentives (e.g. avoided deforestation), and supply of biomass for timber and energy. For Europe, the initial forest aboveground biomass per grid cell was taken from the European forest biomass map from Gallaun et al. (2010). Species-specific biomass expansion factors (Teobaldelli et al. 2009) were used for growing stock-biomass conversion. The main forest management options considered by G4M are variation of thinning and choice of rotation length. The rotation length can be individually chosen but the model can estimate optimal rotation lengths to maximize increment, stocking biomass, or harvestable biomass.

\subsection{Estimating LULUCF sector emissions}

LULUCF emissions are projected using G4M for the forestry sector emissions (afforestation, deforestation, and forest management emissions) and GLOBIOM-EU for the agricultural sector (cropland and grassland management emissions). Both models use an IPCC Tier 3 approach, taking into account soil characteristics and biomass and soil carbon dynamics related to different management systems. Soil carbon emissions from cropland (and ligno-cellulosic crops) are based on dynamic carbon response functions estimated by EPIC. Emissions from harvested wood products (HWP) are calculated based on an IPCC Tier 2 approach. Emissions from wetlands, settlements, and other land are not modeled explicitly but kept constant at 2010 levels using UNFCCC data. Table 1 gives an overview of the datasets and models used to estimate LULUCF areas and emission factors. For more information on the methods and data used for the different sectors we refer to the supplementary material.

Forest area and biomass increment were harmonized with national statistics if available to ensure consistency with national projections. Model and datasets were improved based on bilateral consultations with the EU member states representatives within the EUCLIMIT project (www.euclimit.eu). These mainly resulted in updates to forest inventory data and historic forest harvest rates, improving consistency with UNFCCC reporting.

GLOBIOM-EU and G4M are linked through an iterative procedure. In the first iteration, GLOBIOM-EU provides relevant output variables (i.e. land and commodity prices, forest product demand, and land balances) to G4M which subsequently estimates detailed forest sector activities (forest management, afforestation and deforestation) and emissions for the European forest sector. In the second, afforestation areas are communicated back to GLOBIOM-EU. The scenario is rerun and activity levels for the agricultural sector and related emissions are estimated. 
Table 1 Methodology used to estimate LULUCF emissions

\begin{tabular}{|c|c|c|}
\hline Land category & Area/Supply estimate & Emission factor \\
\hline $\begin{array}{l}\text { Land converted to forest } \\
\text { (afforestation) }\end{array}$ & $\begin{array}{l}\text { G4M estimate, based on } \\
\text { GLOBIOM-EU drivers, calibrated } \\
\text { to historic level (UNFCCC) }\end{array}$ & $\begin{array}{l}\text { Internal forest growth model, } \\
\text { simplified soil emission estimate } \\
\text { based on literature }\end{array}$ \\
\hline $\begin{array}{l}\text { Forest land converted to other } \\
\text { land categories } \\
\text { (deforestation) }\end{array}$ & $\begin{array}{l}\text { G4M estimate, based on } \\
\text { GLOBIOM-EU drivers, calibrated } \\
\text { to historic level (UNFCCC) }\end{array}$ & $\begin{array}{l}\text { Average biomass stock estimated by } \\
\text { G4M, based on remote sensing map }\end{array}$ \\
\hline $\begin{array}{l}\text { Forest land remaining forest } \\
\text { land }\end{array}$ & $\begin{array}{l}\text { Based on country UNFCCC and } \\
\text { Kyoto data or other data bases } \\
\text { (MCPFE) }\end{array}$ & $\begin{array}{l}\text { G4M estimate based on age class } \\
\text { structure, initial biomass stock, } \\
\text { management regime etc. }\end{array}$ \\
\hline $\begin{array}{l}\text { Cropland (Cropland remaining } \\
\text { cropland and land converted } \\
\text { to cropland) }\end{array}$ & $\begin{array}{l}\text { GLOBIOM-EU estimate, calibrated } \\
\text { to historic level (EUROSTAT) }\end{array}$ & $\begin{array}{l}\text { Estimate of biophysical crop model } \\
\text { (EPIC), depending on soil, climate } \\
\text { and crop parameters }\end{array}$ \\
\hline $\begin{array}{l}\text { Grassland (Grassland remaining } \\
\text { grassland and land converted } \\
\text { to grassland) }\end{array}$ & $\begin{array}{l}\text { GLOBIOM-EU estimate, calibrated } \\
\text { to historic level (EUROSTAT) }\end{array}$ & $\begin{array}{l}\text { Country level emission factor based on } \\
\text { UNFCCC data }\end{array}$ \\
\hline $\begin{array}{l}\text { Settlements, wetlands and other } \\
\text { land }\end{array}$ & UNFCCC data, linear extrapolation & UNFCCC data \\
\hline Harvested wood products & $\begin{array}{l}\text { GLOBIOM-EU estimate, calibrated } \\
\text { to historic level (FAO, country } \\
\text { submission) }\end{array}$ & IPCC default values \\
\hline
\end{tabular}

\subsection{Scenarios}

\subsubsection{Reference scenario}

The 2013 Reference scenario provides a "business as usual" scenario for the EU energy, transport, and LULUCF sectors (EC 2013). It assumes full implementation of already adopted policies, including the Renewable Energy Directive and the Energy Efficiency Directive. Basic scenario driver information for Europe such as population and GDP growth as well as feedstock-specific bioenergy demand is based on data from the EC or generated by the GEM-E3 and the PRIMES models (Capros et al. 2014) and taken up by GLOBIOM-EU.

By 2030, the Reference scenario projects a GHG reduction in the EU of $32 \%$ below 1990 levels, a renewable energy share (RES) of $24 \%$ of final energy consumption, and primary energy savings of $21 \%$ in 2030 compared to the business-as-usual projection made in 2007 for 2030 (as projected by PRIMES 2007 Baseline) (Table 2). Biomass and wastes account for $20 \%$ of total primary energy production by 2030 and renewable energy (including biomass) is becoming the dominant energy form (39\% in total primary production). Increasing demand for biofuels results in an increase in imports. Beyond 2020, domestic production catches up, and the share of imported biofuels remains stable until 2030 (EC 2013). All these effects are provided as exogenous drivers to our LULUCF modelling toolbox. Outside Europe, the POLES Baseline scenario (EC 2011) provides bioenergy demand, population, and GDP growth while PRIMES and GEM-E3 data are used for the EU (EC 2013). Productivity increases in the crop sector are based on crop specific yield response functions to GDP per capita growth estimated using a fixed effects model. Efficiency increases in the livestock sector are based on CAPRI Reference (2013) inside Europe. The Reference scenario provides the 
Table 2 EU28 PRIMES results for the different policy scenarios

\begin{tabular}{llll}
\hline & GHG 2030 vs 1990 & $\begin{array}{l}\text { RES 2030 } \\
(\% \text { final En. Cons.) }\end{array}$ & $\begin{array}{l}\text { EE 2030 } \\
\text { (change vs Baseline of 2007.) }\end{array}$ \\
\hline Reference (REF) & $-32.4 \%$ & $24.4 \%$ & $-21.0 \%$ \\
GHG40 & $-40 \%$ & $26.5 \%$ (no pre-set target) & $-25.1 \%$ (no pre-set target) \\
GHG40/EE & $-40 \%$ & $26.4 \%$ (no pre-set target) & $-29.3 \%$ (no pre-set target) \\
GHG40/EE/RES30 & $-40 \%$ & $30 \%$ & $-30.1 \%$ (no pre-set target) \\
GHG45/EE/RES35 & $-45 \%$ & $35 \%$ & $-33.7 \%$ (no pre-set target) \\
\hline
\end{tabular}

benchmark against which the energy policy scenarios from the EC's proposal (EC 2014) are evaluated.

\subsubsection{Policy scenarios}

In order to assess the impacts of alternative climate and energy targets in 2030 we chose four scenarios (Table 2) being discussed in the EU (EC 2014). The scenarios analyzed contain three main policy options:

1. GHG emission reduction targets of 40 and $45 \%$ compared to 1990 emissions levels (GHG40 and GHG45).

2. Explicit additional energy efficiency measures compared to those already present in the reference scenario (EE), decreasing the energy consumption level.

3. Pre-set renewables targets of 30 and $35 \%$ as a share of gross final energy consumption (RES30 and RES35).

The GHG40 scenario reflects the proposal of the Commission for a $40 \%$ GHG reduction and a renewable target of $27 \%$. In this scenario the $27 \%$ is not an explicit target but is calculated by PRIMES to be the result of meeting the $40 \%$ GHG target in the most costeffective way. The GHG40/EE scenario also increases energy efficiency (based on the implementation of a set of specific additional energy efficiency measures) and arrives at a $29.3 \%$ reduction in energy consumption in 2030 (compared to the projection of 2007). The GHG40/EE/RES30 scenario has a more demanding binding renewable target of $30 \%$ and reaches $30 \%$ efficiency. All GHG40 scenarios are therefore built around the objectives for GHG emissions reductions, renewable energy targets, and explicit sets of energy efficiency measures that are currently being discussed in EU.

The GHG45/EE/RES35 scenario takes a more ambitious view (45\% emissions reduction and $35 \%$ renewables share) and serves in this paper as a "high biomass" scenario to show the potential impacts of additional biomass use on the LULUCF sink.

\subsubsection{Scenario drivers}

For the reference and policy scenarios PRIMES outputs for the biomass feedstock split for energy (biofuels and solid biomass) are fed into GLOBIOM-EU while other drivers (macroeconomic, agronomic) are kept constant across scenarios. PRIMES feedstock-specific biomass demand is represented through fixed incorporation levels at member state level while 
competition between bioenergy and other uses (food, feed, and industrial uses) is modelled endogenously in GLOBIOM-EU.

Figure 1 shows biomass demand and domestic feedstock production from PRIMES for the different scenarios. The GHG40/EE scenario has the lowest biomass demand for energy across the policy scenarios as a result of the additional energy efficiency measures that reduce final energy demand and consequently also demand for biomass. In this "low biomass" scenario, biomass demand is even slightly below reference scenario levels. In contrast, the GHG45/EE/ RES35 scenario has the highest biomass demand due to the $45 \%$ GHG mitigation target and the mandatory renewable energy share of $35 \%$. Consequently, the demand for domestic production of biomass feedstock is also higher. In this scenario, additional biomass is mainly sourced from annual (i.e. miscanthus, switchgrass) and perennial ligno-cellulosic crops (i.e. short rotation tree plantations) because of their cost-competitiveness, while forestry removals are only slightly higher compared to the other scenarios.

The GHG40 and GHG40/EE/RES30 represent "middle of the road" scenarios between the "high" (GHG45/EE/RES35) and "low" (GHG40/EE) biomass scenarios. However, as a result of the $30 \%$ renewable energy share in the GHG40/EE/RES30, biomass use from annual lignocellulosic crops is slightly higher in the GHG40/EE/RES30 case than the GHG40 case while other biomass demands are close in the two scenarios. Net imports of bioenergy or biomass feedstock vary somewhat between the scenarios but not significantly. They are lowest for GHG40/EE and highest for GHG45/EE/RES35.

\section{Results and discussion}

\subsection{Reference scenario 2013}

In the reference scenario the EU LULUCF sector continues to be a carbon sink until 2030 (Table 4) even though it is projected to decline from about $-235 \mathrm{MtCO}_{2}$ in 2010 to -192 $\mathrm{MtCO}_{2}$ in $2030(-18 \%)$. This decline is the result of land use activities, with trends in forestry playing the most important role. In general, forest management emissions are driven by the balance of harvest removals and forest increment rates. Harvesting removals continue to rise from 536 million $\mathrm{m}^{3}\left(\mathrm{Mm}^{3}\right)$ in 2010 to $620 \mathrm{Mm}^{3}$ in 2030 because of a growing demand for

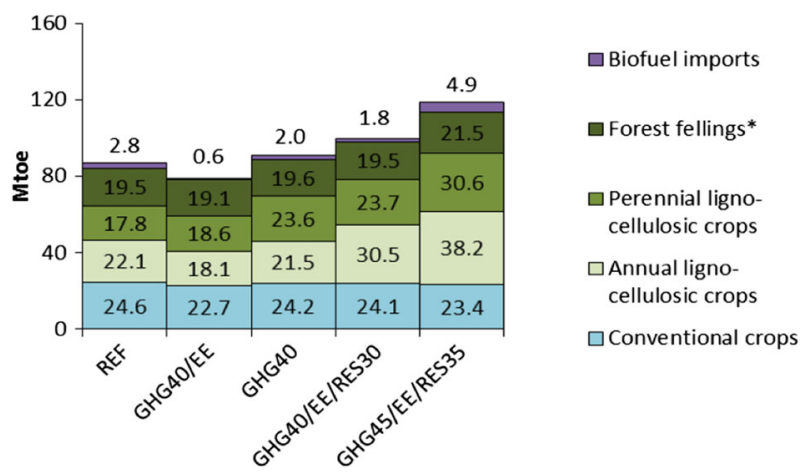

* $41.868 \mathrm{GJ} /$ toe (IEA, 2005); Heating Value: $17 \mathrm{GJ} / \mathrm{t}$ (IEA, 2005); Density: $0.45 \mathrm{t} / \mathrm{m}^{3}$ (UNECE/FAO, 2010)

Fig. 1 EU28 PRIMES biomass demand and domestic feedstock production used in GLOBIOM-EU in Mtoe in 2030 
forestry products (driven mainly by non-energy timber demand through income and population growth but partially by bioenergy demand) which is in line with historic developments over recent decades (Pilli et al. 2015). At the same time, a decline in the average forest increment due to ageing from $6 \mathrm{~m}^{3} /$ ha in 2010 to $5.6 \mathrm{~m}^{3} /$ ha in 2030 is projected. Consequently, the carbon sink in managed forests continuously declines from $-303 \mathrm{MtCO}_{2}$ in 2010 to -126 $\mathrm{MtCO}_{2}$ in 2030. Total forest area is projected to increase from 140 million ha (Mha) in 2010, to $146 \mathrm{Mha}$ in 2030 hence sequestering around $94 \mathrm{MtCO}_{2}$. Carbon sequestration from afforested areas increases over time as new forests are established but young forests that were established over the last 20 years also reach a phase of high biomass production. Until 2030, deforestation drops due to increasing biomass demand and profitability of forest management activities from around 74,000 ha to 23,000 ha resulting in a decrease of emissions from 45 $\mathrm{MtCO}_{2}$ to $12 \mathrm{MtCO}_{2}$. Since part of the harvested biomass is used to produce wood products which have a lifespan of several years, HWP sequester around $-39 \mathrm{MtCO}_{2}$ in 2030. Hence, the significant decline in the managed forests carbon sink is partially compensated by a rising carbon sink from afforestation, a decrease in deforestation, and increasing carbon storage in HWP.

Activities in the agricultural sector have a smaller impact on the total LULUCF sink compared to the forest sector. Cropland area increases by around 5 Mha until 2030, mainly driven by the production of ligno-cellulosic crops for bioenergy use. Despite the expansion, net carbon emissions from cropland are projected to decline by some $40 \%$ of emissions compared to 2010, as a result of the cultivation of ligno-cellulosic crops. Typically these plants provide more litter input for the soil and the management activities disturb the soil less compared to annual food crops, leading to a reduced loss or even an accumulation of soil carbon. By 2030 the area covered by ligno-cellulosic crops reaches 7 Mha (7\% of total cropland). Total emissions from grasslands are expected to go down as more land is projected to be converted to grassland that typically tends to sequester additional carbon. Grassland stores around 5 $\mathrm{MtCO}_{2}$ by 2030 .

\subsection{Policy scenarios for the new EU climate and energy targets}

We assessed the impact of four alternative climate and energy policies on the EU LULUCF sink and contrasted these results with the reference scenario. Total solid biomass removal from forests and short rotation tree plantations (perennial ligno-cellulosic crops) range from $719 \mathrm{Mm}^{3}$ to $799 \mathrm{Mm}^{3}$ (Fig. 2) by 2030 across the policy scenarios compared to $718 \mathrm{Mm}^{3}$ in the reference. While in the GHG40/EE scenario only a marginal increase in solid biomass use is observed (as a result of additional energy efficiency measures), significantly higher biomass use is projected for the other policy scenarios. This is driven either by the lack of additional energy efficiency measures (GHG40), the presence of an obligatory renewable energy share (GHG40/EE/RES30) or a higher GHG reduction target in combination with higher renewable energy share (GHG45/EE/RES35). The highest solid biomass use is projected for the GHG45/EE/RES35 with $799 \mathrm{Mm}^{3}$ followed by GHG40 and GHG40/EE/ RES30 with around $752 \mathrm{Mm}^{3}$. The lowest use occurs in the GHG40/EE with $719 \mathrm{Mm}^{3}$, hardly higher than in the reference case. Solid biomass use is similar in the GHG40 and GHG40/EE/ RES30 scenario, however the demand for annual ligno-cellulosic crops is substantially higher in the GHG40/EE/RES30 scenario than in the GHG40 (Fig. 1).

The solid biomass shares directly follow PRIMES projections as presented in Fig. 2, meaning that harvest removals from the forest sector remain rather stable across scenarios 
Fig. 2 EU28 harvest removals from forest and short rotation tree plantations across scenarios in $\mathrm{Mm}^{3}$ overbark in 2030

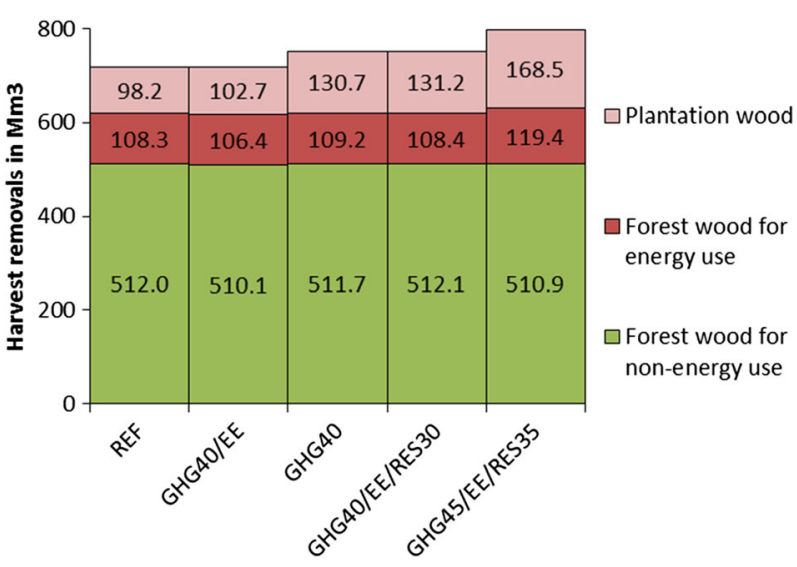

while most of the additional biomass is projected to come from ligno-cellulosic crops. This development particularly applies for the scenarios with obligatory renewable energy targets or without additional energy efficiency measures. Differences in harvest removals for the nonenergy sector are driven endogenously in GLOBIOM-EU by differences in biomass prices resulting from the competition with biomass for energy use.

The land use changes expected to meet the increased biomass demand for bioenergy in the policy scenarios are presented in Table 3. Except for the GHG40/EE scenario, where less biomass for bioenergy is being produced on cropland (Fig. 1), cropland increases in all policy scenarios (even though this is quite limited in all scenarios except the GHG45/EE/RES35). As additional agricultural biomass demand is mainly sourced from ligno-cellulosic crops, cropland area increases with increasing biomass demand. Ligno-cellulosic crops are mainly planted on existing cropland thereby directly competing with food crops but they are also partially established on unused land (abandoned crop- and grassland, marginal land) and to a much smaller extent on grassland. In the "high biomass" (GHG45/EE/RES35) scenario, total ligno-cellulosic crop area increases by 5 Mha compared to the reference of which 1.5 Mha are established on unused land while the remaining area increase of 3.5 Mha takes place on existing cropland, replacing conventional food and feed crops. Consequently, cereal net exports decrease by $40 \%$, as production $(-1.5 \%)$ is being displaced by energy crops. In this scenario emissions from land use change could increase by 4 $\mathrm{MtCO}_{2}$ in 2030 outside Europe due to the conversion of native vegetation. ${ }^{2}$ In the remaining scenarios (GHG40, GHG40/EE, and GHG40/EE/RES30) a much more modest increase in cropland (if at all) can be observed; the result of limited additional biomass demand. Therefore, impacts on land use and agricultural commodity markets are minor. To conclude, cropland expansion across policy scenarios inside the EU is mainly driven by the production of lignocellulosic crops for bioenergy from which approximately two thirds is grown on existing cropland and one third through cropland expansion. However, only in the GHG45/EE/RES35 scenario an impact on European net trade balance and global GHG emissions occurs. In the other scenarios, cropland management changes compensate for small area decreases of food crops.

With respect to emissions, the biggest decrease in the EU LULUCF sink can be observed in the GHG45/EE/RES35 scenario with ambitious EE and RES policies (Table 4). In this

\footnotetext{
${ }^{2}$ Emissions from land use change represent only part of the LULUCF emission sources estimated for the EU (i.e. only cover above- and belowground biomass changes). Hence, GHG impacts outside the EU are likely to be underestimated.
} 
Table 3 EU28 land balance across scenarios in Mha in 2030

\begin{tabular}{lccccc}
\hline & REF & GHG40/EE & GHG40 & GHG40/EE/RES30 & GHG45/EE/RES35 \\
\hline Forest land & 145.7 & 145.8 & 145.7 & 145.7 & 145.7 \\
Cropland & 105.2 & 104.5 & 105.6 & 105.9 & 106.7 \\
Grassland & 61.9 & 61.8 & 61.7 & 61.7 & 61.6 \\
Other land & 74.8 & 74.8 & 74.8 & 74.8 & 74.8 \\
Unused land & 58.6 & 59.3 & 58.4 & 58.2 & 57.3 \\
Perennial area & 7.1 & 6.9 & 8.5 & 9.5 & 12.0 \\
\% of total cropland & $6.7 \%$ & $6.6 \%$ & $8.1 \%$ & $9.0 \%$ & $11.2 \%$ \\
\hline
\end{tabular}

scenario the LULUCF sink declines by around $6 \mathrm{MtCO}_{2}(-3 \%)$ compared to the reference as forest harvest removals increase from $620 \mathrm{Mm}^{3}$ in the reference to $630 \mathrm{Mm}^{3}$ to meet biomass demand for bioenergy. This translates in reduction of the forest management sink from -126.4 $\mathrm{MtCO}_{2}$ in the reference to $-115.5 \mathrm{MtCO}_{2}$. This relatively small increase in harvest removals already shows a reduction of the forest management sink by $1.1 \mathrm{tCO}_{2}$ per $\mathrm{m}^{3}$ additional forest harvest, which is consistent with Böttcher et al. (2012). The negative effect on the forest sink is partially compensated by the increases in plantation wood to $169 \mathrm{Mm}^{3}\left(98 \mathrm{Mm}^{3}\right.$ in the reference) which has a positive net effect on the amount of carbon stored in the soil and biomass compared to other annual crops normally planted on cropland (Rytter 2012). Therefore, cropland emissions are lower $\left(10 \mathrm{MtCO}_{2}\right)$ compared to the reference $\left(14 \mathrm{MtCO}_{2}\right)$ as carbon sequestration overcompensates emissions from cropland expansion. Consequently, the net impact of the GHG45/EE/RES35 scenario on the total LULUCF sink is smaller than the impact on the forest sector only. Nevertheless, substituting ligno-cellulosic crop biomass with forest biomass would significantly impact the LULUCF sink as direct emissions from the forest sector management would increase while at the same time less carbon would be sequestered on cropland. In the other scenarios, the LULUCF sink does not differ significantly from the reference scenario because additional biomass is mostly sourced from ligno-cellulosic crops on existing cropland and is not taken out from the forest.

To conclude, we observe only a limited impact of different bioenergy targets on the European LULUCF sink when compared to the reference scenario. The biggest decline takes place in the

Table 4 EU28 LULUCF emissions across scenarios in $\mathrm{MtCO}_{2}$ in 2030

\begin{tabular}{llllll}
\hline & REF & GHG40/EE & GHG40 & GHG40/EE/RES30 & GHG45/EE/RES35 \\
\hline Total LULUCF emissions & -192.2 & -193.5 & -190.5 & -192.5 & -186.1 \\
\% change to Reference & & $1 \%$ & $-1 \%$ & $0 \%$ & $-3 \%$ \\
Total forest land & -207.6 & -210.5 & -205.5 & -205.9 & -196.3 \\
of which forest management & -126.4 & -129.3 & -124.5 & -125.0 & -115.5 \\
of which afforestation/reforestation & -93.5 & -93.3 & -93.3 & -93.3 & -93.2 \\
of which deforestation & 12.3 & 12.1 & 12.2 & 12.3 & 12.4 \\
Total cropland & 14.4 & 15.2 & 14.1 & 12.6 & 9.9 \\
Total grassland & -4.9 & -4.8 & -5.0 & -5.1 & -5.0 \\
Harvested wood products & -38.9 & -38.2 & -38.8 & -38.9 & -39.4 \\
Wetlands, settlements, other land & 44.8 & 44.8 & 44.8 & 44.8 & 44.8 \\
\hline
\end{tabular}


GHG45/EE/RES35 with a decrease of $3 \%\left(6 \mathrm{MtCO}_{2}\right)$. To put this in context: the GHG45/EE/ RES35 scenario reduces total GHG emissions (except LULUCF) in the EU by $45 \%$ and not $40 \%$ (as in the other policy scenarios) compared to 1990. This corresponds to an additional reduction of around $280 \mathrm{MtCO}_{2}$ eq. Overall the impacts on the LULUCF sink seem limited, partly because increased demand for bioenergy is met largely through increased use of ligno-cellulosic energy crops, partly because of increased demand for biomass being met by imports for the GHG45/EE/ RES35 scenario that achieves $35 \%$ RES. If more biomass were sourced from existing forests, the LULUCF sink could significantly decrease still further. In addition, the GHG45/EE/RES35 scenario would imply a substantial expansion of cropland for bioenergy on existing cropland. The increasing share of ligno-cellulosic crops results in a decrease in available cropland for other uses (food and feed) and affects the net trade balance of the EU for agricultural commodities (especially cereals), land use change emissions outside the EU, and biofuel imports from the rest of the world. Overall, demand quantities decline slightly as prices increase, driven by the additional demand for biomass. On the supply side changes in management systems in the crop- and livestock sector and reallocation of production help compensate for the decrease in available conventional cropland area. In the other policy scenarios, only marginal impacts on net trade are observed.

\subsection{Comparison with previous assessments}

We project that the EU LULUCF sink will decline in the reference until 2030 as a result of increased harvest and forest ageing. This is in line with other studies which predict a decrease in carbon uptake from forests. Comparing our results with Böttcher et al. (2012), we project a higher decrease in forest management sink (58 \%) compared to their results of 25-40\% which is related to different harvest removals in 2030. While we project an increase of total harvest removals from forest to around $620 \mathrm{Mm}^{3}$ for EU28 by 2030 ( $+16 \%$ rise compared to 2010), Böttcher et al. (2012) projected only limited growth after 2010 (stagnation at around $530 \mathrm{Mm}^{3}$ in 2030). Verkerk et al. (2011) estimate the realizable biomass potential from forests (stemwood, residues, stumps, and other biomass) around 623 to $895 \mathrm{Mm}^{3}$ in 2030 .

Results depend on the feedstock-specific biomass demand projections from PRIMES. In the reference scenario, biomass from plantations is projected to increase to around $98 \mathrm{Mm}^{3}$ while in the policy scenario this can go up to $169 \mathrm{Mm}^{3}$ in the most ambitious bioenergy scenario. Lauri et al. (2014) estimate the biomass potential from plantations to be around $240 \mathrm{Mm}^{3}$ given an energy price of $30 \$ / G J$ by 2050 . However, future demand of ligno-cellulosic biomass for energy depends on the economic profitability (Böttcher et al. 2012) as well as other constraints such as risk aversion of farmers, market access, or concerns about the stability of income (Sherrington et al. 2008) which may limit future expansion of plantations. Recent EUROSTAT statistics report stagnation or even a decrease of ligno-cellulosic crop areas in some countries (i.e. Finland, Ireland, or UK). Therefore, it remains uncertain whether the share of biomass from ligno-cellulosic crops assumed in this paper will be actually supplied by 2030 .

\section{Conclusions}

In this paper, we assess the impact of the agreed $40 \%$ GHG reduction target on the EU LULUCF sector using a series of alternative 2030 climate and energy scenarios (EC 2014). We conclude that implementing a $40 \%$ GHG reduction target by 2030 may only have a small 
negative impact $(-1 \%)$ on the domestic LULUCF sink if the additional biomass demand is largely met through lingo-cellulosic energy crops rather than forest removals. However, the feasibility of large scale establishment of these crops will depend on the economic profitability and other non-financial barriers of adoption (Sherrington et al. 2008). Even though some studies estimate a significant biomass potential from ligno-cellulosic biomass (GEA 2012; Klein et al. 2014) others remain more cautious (Haberl et al. 2013).

A more pronounced decrease in the LULUCF sink due to increased forest harvest can be observed in the "high biomass" scenario where we estimate a reduction by $-3 \%$ of the LULUCF sink. This scenario illustrates the potential implications for the forest carbon sink if additional biomass is sourced from existing forests, and shows average emissions of $1.1 \mathrm{tCO}_{2}$ from soil and biomass per additional $\mathrm{m}^{3}$ forest harvest. If the increased biomass demand is met exclusively through higher forest harvest removals, a significantly higher impact can be expected. In the "high biomass" scenario, we also observe high displacement of food crops with ligno-cellulosic crops as they compete for cropland, which impacts agricultural commodity markets. This scenario shows negative displacement effects as additional biomass demand for energy production puts pressure on the forest and agricultural sector, driving adjustments on the demand and supply side in- and outside Europe unless additional biomass could be diverted from other sectors. Other studies also suggest that indirect impacts outside Europe could significantly decrease domestic emission reductions through emission leakage (Britz and Hertel 2011; Laborde 2011). Hence, if additional biomass for energy production is not mainly supplied by ligno-cellulosic crops but conventional food crops, the impacts could even be amplified (Havlík et al. 2011).

Extracting biomass from existing forests for bioenergy production decreases the forest sink; however, producing biomass on cropland competes with non-bioenergy uses. The potential impacts of both of these options in- and outside Europe need to be carefully considered when assessing regional bioenergy policies. Further research is needed to quantify potential global implications also taking into account the commitments made during the COP21 climate negotiations in Paris.

Acknowledgments This study was financially supported by the European Commission - DG Climate Action through the tender contract 'Development and application of EU economy-wide climate change mitigation modelling capacity (all greenhouse gas emissions and removals)', contract ref no. 071303/2011/600928/SER/ CL1MA.A.4. www.euclimit.eu. The views expressed are purely those of the authors and may not be regarded as stating an official position of the European Commission. We would like to thank Giacomo Grassi for his comments and the PRIMES team for providing biomass scenarios.

Open Access This article is distributed under the terms of the Creative Commons Attribution 4.0 International License (http://creativecommons.org/licenses/by/4.0/), which permits unrestricted use, distribution, and reproduction in any medium, provided you give appropriate credit to the original author(s) and the source, provide a link to the Creative Commons license, and indicate if changes were made.

\section{References}

Bauer J, Kniivilä M, Schmithüsen F (2004) Forest legislation in Europe: how 23 countries approach the obligation to reforest, public access and use of non-wood forest products. Geneva Timber and Forest Discussion Paper. FAO, Geneva, p. 39

Bellassen V, Viovy N, Luyssaert S, Le Maire G, Schelhaas M-J, Ciais P (2011) Reconstruction and attribution of the carbon sink of European forests between 1950 and 2000. Glob Chang Biol 17:3274-3292

Böttcher H, Verkerk PJ, Gusti M, Havlík P, Grassi G (2012) Projection of the future EU forest CO2 sink as affected by recent bioenergy policies using two advanced forest management models. GCB Bioenergy 4 : 773-783 
Britz W, Hertel TW (2011) Impacts of EU biofuels directives on global markets and EU environmental quality: an integrated PE, global CGE analysis. Agric Ecosyst Environ 142:102-109

Capros P, Paroussos L, Fragkos P, Tsani S, Boitier B, Wagner F, Busch S, Resch G, Blesl M, Bollen J (2014) Description of models and scenarios used to assess European decarbonisation pathways. Energy Strateg Rev 2:220-230

Ciais P, Schelhaas MJ, Zaehle S, Piao SL, Cescatti A, Liski J, Luyssaert S, Le-Maire G, Schulze ED, Bouriaud O, Freibauer A, Valentini R, Nabuurs GJ (2008) Carbon accumulation in European forests. Nat Geosci 1:425-429

Delbeke J, Vis P (2015) EU climate policy explained. Routledge, London

EC (2009) Directive 2009/28/EC of the European Parliament and of the Council of 23 April 2009 on the promotion of the use of energy from renewable sources and amending and subsequently repealing Directives 2001/77/EC and 2003/30/EC in Union TEPaCotE (ed.), Brussels, p. 107

EC (2011) Impact assessment - A Roadmap for moving to a competitive low carbon economy in 2050. European Commission (EC), Brussels, p 133

EC (2013) EU Energy, Transport and GHG Emissions Trends to 2050: Reference Scenario 2013. European Commission Directorate-General for Energy, DG Climate Action and DG Mobility and Transport., Brussels, p. 168

EC (2014) Commission staff working document. Executive summary of the impact assessment. Communication from the Commission to the European Parliament, the Council, the European Economic and Social Committee and the Committee of the Regions. A policy framework for climate and energy in the period from 2020 to 2030. European Commission, Brussels, p. 18

Frank S, Schmid E, Havlík P, Schneider UA, Böttcher H, Balkovič J, Obersteiner M (2015) The dynamic soil organic carbon mitigation potential of European cropland. Glob Environ Chang 35: 269-278

Fuchs R, Herold M, Verburg PH, Clevers JG, Eberle J (2015) Gross changes in reconstructions of historic land cover/use for Europe between 1900 and 2010. Glob Chang Biol 21:299-313

Gallaun H, Zanchi G, Nabuurs GJ, Hengeveld G, Schardt M, Verkerk PJ (2010) EU-wide maps of growing stock and above-ground biomass in forests based on remote sensing and field measurements. For Ecol Manag 260: $252-261$

GEA (2012) Global energy assessment-toward a sustainable future, Cambridge University Press, Cambridge, UK and New York, NY, USA and the International Institute for Applied Systems Analysis, Laxenburg, Austria

Gusti M (2010) An algorithm for simulation of forest management decisions in the global forest model. Artif Intell N4:45-49

Haberl H, Erb K-H, Krausmann F, Running S, Searchinger TD, Smith WK (2013) Bioenergy: how much can we expect for 2050? Environ Res Lett 8:031004

Havlík P, Schneider UA, Schmid E, Böttcher H, Fritz S, Skalský R, Aoki K, Cara SD, Kindermann G, Kraxner F, Leduc S, McCallum I, Mosnier A, Sauer T, Obersteiner M (2011) Global land-use implications of first and second generation biofuel targets. Energ Policy 39:5690-5702

Havlík P, Valin H, Herrero M, Obersteiner M, Schmid E, Rufino MC, Mosnier A, Thornton PK, Böttcher H, Conant RT, Frank S, Fritz S, Fuss S, Kraxner F, Notenbaert A (2014) Climate change mitigation through livestock system transitions. Proc Natl Acad Sci 111:3709-3714

IEA (2005) Energy statistics manual. IEA, Paris, p. 196

IPCC (2014) Climate change 2014: mitigation of climate change. Contribution of working group III to the fifth assessment report of the intergovernmental panel on climate change. Cambridge University Press, Cambridge

Kindermann G, Obersteiner M, Sohngen B, Sathaye J, Andrasko K, Rametsteiner E, Schlamadinger B, Wunder S, Beach R (2008) Global cost estimates of reducing carbon emissions through avoided deforestation. Proc Natl Acad Sci U S A 105:10302-10307

Klein D, Humpenöder F, Bauer N, Dietrich JP, Popp A, Bodirsky BL, Bonsch M, Lotze-Campen H (2014) The global economic long-term potential of modern biomass in a climate-constrained world. Environ Res Lett 9: 074017

Laborde D (2011) Assessing the land use change consequences of European biofuel policies final report. IFPRI, Washington, DC, p. 111

Lauri P, Havlík P, Kindermann G, Forsell N, Böttcher H, Obersteiner M (2014) Woody biomass energy potential in 2050. Energ Policy 66:19-31

Mantau U, Saal U, Prins K, Steierer F, Lindner M, Verkerk H, Eggers J, Leek N, Oldenburger J, Asikainen A, Anttila P (2010) EUwood - real potential for changes in growth and use of EU forests. Final report to the European Commission DG TREN. University of Hamburg, Hamburg

Nabuurs G-J, Lindner M, Verkerk PJ, Gunia K, Deda P, Michalak R, Grassi G (2013) First signs of carbon sink saturation in European forest biomass. Nat Clim Chang 3:792-796

Obersteiner M, Böttcher H, Yamagata Y (2010) Terrestrial ecosystem management for climate change mitigation. Curr Opin Environ Sustain 2:271-276 
Pilli R, Fiorese G, Grassi G (2015) EU mitigation potential of harvested wood products. Carbon Balance Manage 10:6

Rytter R-M (2012) The potential of willow and poplar plantations as carbon sinks in Sweden. Biomass Bioenergy 36:86-95

Sherrington C, Bartley J, Moran D (2008) Farm-level constraints on the domestic supply of perennial energy crops in the UK. Energ Policy 36:2504-2512

Skalský R, Tarasovičová Z, Balkovič J, Schmid E, Fuchs M, Moltchanova E, Kindermann G, Scholtz P (2008) GEO-BENE global database for bio-physical modeling v. 1.0 - concepts, methodologies and data. The GEOBENE database report. International Institute for Applied Systems Analysis (IIASA), Austria, p. 58

Soussana JF, Loiseau P, Vuichard N, Ceschia E, Balesdent J, Chevallier T, Arrouays D (2004) Carbon cycling and sequestration opportunities in temperate grasslands. Soil Use Manag 20:219-230

Teobaldelli M, Somogyi Z, Migliavacca M, Usoltsev VA (2009) Generalized functions of biomass expansion factors for conifers and broadleaved by stand age, growing stock and site index. For Ecol Manag 257:1004 1013

UNECE/FAO (2010) Forest product conversion factors for the UNECE region. UNECE/FAO, Geneva, p. 50

Verkerk PJ, Anttila P, Eggers J, Lindner M, Asikainen A (2011) The realisable potential supply of woody biomass from forests in the European Union. For Ecol Manag 261:2007-2015

Williams JR (1995) The EPIC model. In: Singh VP (ed) Computer models of watershed hydrology. Water Resources Publications, Highlands Ranch, pp. 909-1000 